\title{
Extraction of hydrocolloids from Pereskia Aculeata Miller: reuse of process residue as activated carbon for the pigment-removal phase
}

\author{
Tatiana Nunes AMARAL ${ }^{1}$, Luciana Affonso JUNQUEIRA ${ }^{1}$, Cibele Cristina Oliveira ALVES ${ }^{1}$, \\ Natália Leite OLIVEIRA ${ }^{1}$, Mônica Elisabeth Torres PRADO ${ }^{1}$, Jaime Vilela de RESENDE ${ }^{1 *}$
}

\begin{abstract}
Hydrocolloids of Pereskia aculeata Miller (OPNH) are potential ingredients in food industry as emulsifiers and stabilizers. The extraction process of OPNH requires the removal of pigments with activated carbon. Because this step is critical to the quality of the ingredient and has an impact on costs, a new activated carbon has been developed with residues from the same process. Residues activated with $\mathrm{NaOH}$ and $\mathrm{H}_{3} \mathrm{PO}_{4}\left(300^{\circ} \mathrm{C}, 1 \mathrm{~h}\right)$ were subjected to batch adsorption tests in model solutions of malachite green (MG), carbohydrate and protein. Residue treated with $85 \% \mathrm{H}_{3} \mathrm{PO}_{4}(\mathrm{OPNAC})$ had higher productivity and MG adsorption capacity, displaying a predominantly microporous surface (MEV/BET) with chemical activation confirmed by TG/FTIR. OPNAC showed higher MG and protein adsorption capacity than the commercial activated carbon (CAC) did. Results for MG-adsorption capacity by OPNAC did not show significant differences in the presence of protein and carbohydrate, presenting the higher affinity of the adsorbent for the dye. Adsorption isotherms showed OPNAC to be more favorable to MG adsorption than CAC, and to have a good fit to Langmuir-Freundlich model. OPNAC made it possible to reduce costs and allowed the sustainability of the process, leading to increased efficiency in selective pigment removal compared with CAC.
\end{abstract}

Keywords: adsorption; carbohydrate; malachite green; protein; sustainable process.

Practical Application: The activated carbon obtained using solid residues of the extraction process of hydrocolloids from Pereskia aculeata Miller proved to be more effective in protein and pigment adsorptions and less effective in carbohydrate adsorption when compared to using a commercial activated carbon. The potential use is waste treatment systems and clarification process.

\section{Introduction}

Hydrocolloids are functional ingredients used in the food industry for the control of microstructure, texture, flavor and shelf-life. (Dickinson, 2003). As a result of the increasing demand for hydrocolloids with specific functionality in recent years, the search for new hydrocolloid sources with appropriate properties is an active area of study (Salehi et al., 2014). Plant-derived hydrocolloids have a friendlier image for consumers compared with hydrocolloids derived from animals (Vardhanabhuti \& Ikeda, 2006) and number of studies have been carried out to develop hydrocolloids from new vegetable sources (Capitani et al., 2013; Petera et al., 2015).

Hydrocolloids used in the Brazilian food industry are from imported products, despite the fact that the country has native plants with high potential for hydrocolloid production, though their commercial and industrial uses have not been fully investigated (Merce et al., 2001). Aiming to provide a new vegetable source for hydrocolloid production, Lima et al. (2013) explored the hydrocolloid extraction process from Pereskia aculeata Miller.

Pereskia species are considered a general model of the morphology and physiology of ancestral cacti characteristics, preserving some primitive features lost in other genera. In Brazil, Pereskia aculeata is popularly known as ora-pro-nobis (OPN), its leaves are traditionally used in regional cuisine and is also used as an emollient, due to their high mucilage content (Takeiti et al., 2009). Mucilage is a complex polysaccharide with high water absorption capacity that represents a potential source for industrial food hydrocolloids as binder and thickening agent in food. Mucilages from cactus were largely described as arabinogalactan-rich polysaccharides made up of galactose, arabinose, rhamnose and galacturonic acid (Sáenz et al., 2004). OPN leaves are rich in high-quality and highly digestible proteins, with a $25 \%$ protein content (Takeiti et al., 2009).

The extraction process of OPN hydrocolloids (OPNH) is shown in Figure 1 (Lima et al., 2013). This process consisted of the hot extraction of raw material previously triturated with water. The solid material resulting was subjected to the Pressing step, and the liquid fraction was mixed with the result of Filtration 1, forming Extract 1. The Filtration 1 step consisted of a vacuum filtration, and Extract 1 was placed in a fixed-bed column with commercial activated carbon to remove pigments (Filtration 2), 


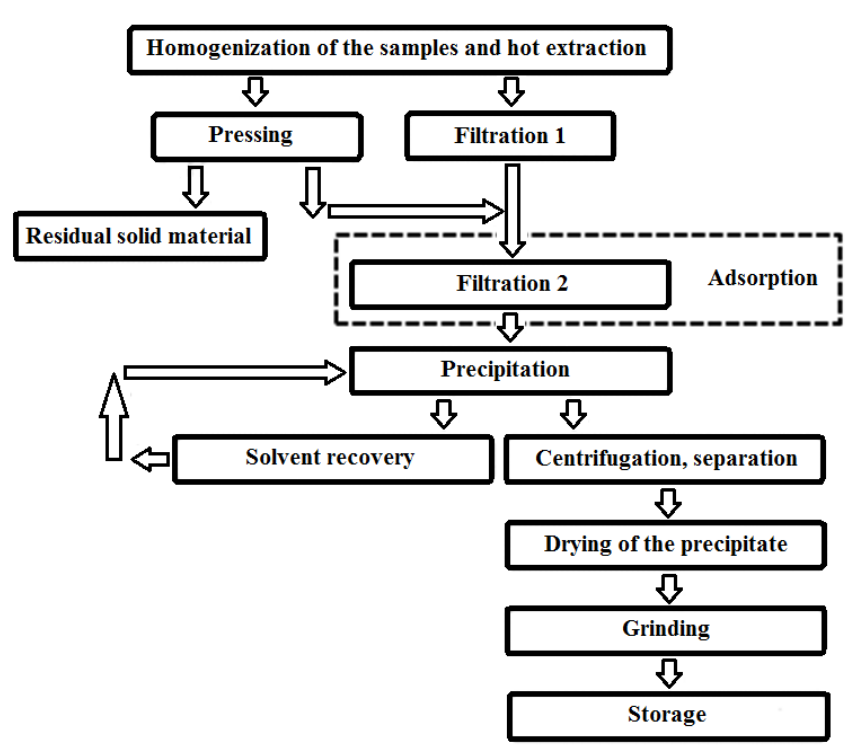

Figure 1. Extraction process of Pereskia aculeata Miller hydrocolloids.

resulting in Filtrate 2, which was subjected to precipitation in ethyl alcohol.

Conceição et al. (2014) adapted this process and performed hydrocolloid extraction considering the optimization of its parameters. One of the changes was to use only the OPN leaves, generating solid residues like plant branches in the process. This material could be transformed into activated carbon for the application of reuse in the same process for the removal of pigments, making it sustainable. Adsorption using activated carbon (AC) has proved to be very effective in the removal of dyes. However, complex media, as is the case of hydrocolloid extracts, where components must be preserved, requires the use of adsorbents with specificity and selectivity. Many researchers have studied the production of AC using renewable and cheaper precursors which are mainly industrial and agricultural by-products (Alves et al., 2013; Clark et al., 2012; Reffas et al., 2010).

In view of the aforementioned considerations, the objectives of this work were to evaluate the characteristics of activated carbon based on solid residue from the extraction of $\mathrm{OPNH}$, in a sustainable and cheaper process, and its effects on pigment removal, preserving important components like carbohydrates and proteins.

\section{Materials and methods}

\subsection{Materials}

OPN was obtained in May 2015 on UFLA Campus (Lavras - Brazil) for use in the present experiments.

\subsection{Adsorbent preparation}

OPN residue (branches) was dried at $105^{\circ} \mathrm{C}$, chopped and impregnated with the corresponding treatment for 3 min, followed by $1 \mathrm{~h}$ activation in a muffle furnace at $300^{\circ} \mathrm{C}$.
The activation solutions tested were $42.5 \%, 72.2 \%$ and $85.0 \%$ $\mathrm{H}_{3} \mathrm{PO}_{4}$; and $10 \%, 15 \%$ and $20 \% \mathrm{NaOH}$, considering $100 \%$ impregnation rate. The material was rinsed with distilled water until the $\mathrm{pH}$ was around 6.5 and dried at $105^{\circ} \mathrm{C}$ for $24 \mathrm{~h}$. The dried material was ground and sieved to 1 to $2 \mathrm{~mm}$, the same size of commercial activated carbon (Dinâmica Química - Brazil) (CAC), the standard adsorbent used in the original OPNH extraction process (Conceição et al., 2014). Prior to use, CAC was rinsed with distilled water to remove the fines and ovendried at $105^{\circ} \mathrm{C}$.

\subsection{Preparation of model solutions}

Aqueous model solutions were prepared with malachite green $(\mathrm{MG})$ dye to simulate the adsorption of OPNH pigments by the OPN activated carbons with different activating agents and the CAC.

The optimum OPN activated carbon chosen (OPNAC) and $\mathrm{CAC}$ were subjected to adsorption tests in different aqueous model solutions based on the material (Extract 1) before the pigment-removal phase (Filtration 2) in the OPNH extraction process shown in Figure 1. These solutions were composed of MG, protein and/or carbohydrate.

Extract 1 is a dark green mucilage rich in carbohydrates and proteins (Conceição et al., 2014). To define the composition of the model solutions, the Extract 1 was produced and the following variables were measured: luminosity ( $L^{*}$ - Minolta Chroma Meter CR 200 colorimeter, Osaka - Japan), attributed to the concentration of pigments; carbohydrate content (Anthrone method described by Dische, 1962); and protein content (Bradford, 1976). The single component solutions used were $50 \mathrm{mg} \mathrm{L}^{-1} \mathrm{MG}$ (corresponding to $\mathrm{L}^{*}=32$ ), $500 \mathrm{mg} \mathrm{L}^{-1}$ protein (bovine serum albumin - BSA -Sigma-Aldrich) and $1500 \mathrm{mg} \mathrm{L}^{-1}$ carbohydrate (anhydrous glucose PA - GLU - CRQ brand). The tertiary aqueous solution considered the mixture of MG, BSA and GLU. For the OPNH extraction process, maximum pigment adsorption and low carbohydrate and protein adsorption are required, since these components are the base of the final product.

\subsection{Adsorbent characterization}

The OPN residue-based carbons activated with the different agents were assessed for density and adsorbent yield. Density was defined as the ratio between the mass and volume of the material studied. Adsorbent yield was calculated using Equation 1. The OPN residue-based activated carbon chosen with the best activating agent was termed as OPNAC.

yield $(\%)=\left(W_{1} * 100\right) / W_{0}$

where $\mathrm{W}_{1}(\mathrm{~g})$ is the weight of dried OPN activated carbon and $\mathrm{W}_{0}(\mathrm{~g})$ is the weight of OPN residue mass (branches dried at $\left.105^{\circ} \mathrm{C}\right)$.

The OPNAC adsorbent surface was evaluated by Scanning Electron Microscopy (Nano Technology Systems, Carl Zeiss, Oberkochen, Germany, Evo 40 VP). Specific surface area and pore volume determinations were based on nitrogen adsorption isotherms at $-196.6^{\circ} \mathrm{C}$ (Autosorb and Quantachrome NOVA). Specific surface 
area was calculated by the Brunauere-Emmette-Teller (BET) method; pore size and total volume were calculated by the Barrete-Joynere-Halenda equation; whereas micropore volume was calculated by the $\mathrm{t}$-method.

OPNAC was subjected to thermogravimetric measurements (TG) carried out on a NETZSCH STA409EP instrument (Selb, Germany), considering air dynamic atmosphere and a temperature range of $21-945^{\circ} \mathrm{C}$ at $10^{\circ} \mathrm{C} \mathrm{min}^{-1}$. OPNAC was also investigated using Fourier Transform Infrared (FTIR) spectroscopy, before and after chemical activation. The FTIR spectra were obtained and recorded on a FTIR spectrometer (Vertex 70, Bruker, Germany) operating in the range of $400-4000 \mathrm{~cm}^{-1}$, with a resolution of $4 \mathrm{~cm}^{-1}$, coupled to a UATR- Universal Attenuated Total Reflectance.

\subsection{Adsorption studies}

Batch adsorption studies were conducted to evaluate the effect of activation on OPN residue. One hundred milliliters of each model solution and an adsorbent dose of $10 \mathrm{~g} \mathrm{~L}^{-1}$ were used in $250 \mathrm{~mL}$ Erlenmeyer flasks, as determined by initial experiments on the maximum capacity of adsorption of MG. Flasks were agitated on a shaker at $100 \mathrm{rpm}$ at $25^{\circ} \mathrm{C}$. Aliquots of $0.5 \mathrm{~mL}$ were taken at each time interval. Adsorption tests were performed in distilled water (blank) in triplicate to reduce the error of the measurements. The effect of contact time of the different activated carbons was evaluated in a period from $5 \mathrm{~min}$ to $6 \mathrm{~h}$, and the initial MG concentration was $10 \mathrm{mg} \mathrm{L}^{-1}$ (Mall et al., 2005).

The sample with the best performance (OPNAC) was subjected to physical-chemical characterization (item 2.4). The effect of contact time on MG, BSA and GLU adsorption by OPNAC and CAC was evaluated in a period from $5 \mathrm{~min}$ to $24 \mathrm{~h}$ in the single and tertiary aqueous solution (item 2.3). The adsorption isotherms were studied in the concentration range from 10 to $170 \mathrm{mg} \mathrm{L}^{-1} \mathrm{MG}$ (24h).

Malachite green $(\mathrm{MG})$ concentration was determined using a UV-Vis spectrophotometer at $620 \mathrm{~nm}$. Protein analyses were performed according to Bradford (1976); BSA was used as standard, and results were expressed in mg equivalent of BSA per gram of adsorbent. Carbohydrates were determined by the Anthrone method (Dische, 1962);GLU was used as standard, and results were expressed in mg equivalent of GLU per gram of adsorbent. All samples were analyzed in a UV-vis spectrophotometer (Varian Cary 50 Probe, California, USA) at the wavelength of $620 \mathrm{~nm}$ for carbohydrates or at $595 \mathrm{~nm}$ for protein. Calibration curves were prepared for each determination.

The activated-carbon adsorption capacity $\left(\mathrm{q}_{\mathrm{t}} \mathrm{mg} \mathrm{g}^{-1}\right)$ was calculated using Equation 2.

$q_{t}=\left[\left(C_{0}-C_{t}\right) \times V\right] / W$

where $\mathrm{C}_{0}$ and $\mathrm{C}_{\mathrm{t}}\left(\mathrm{mg} \mathrm{L}^{-1}\right)$ are the adsorbate concentrations at initial and sampling times, respectively, $\mathrm{V}$ is the volume of the solution (L), and W is the mass of dry adsorbent used (g).

Evaluation of each model's ability to predict the experimental data was based on both regression correlation coefficient values $\left(\mathrm{R}^{2}\right)$ and difference between experimental $\left(\mathrm{q}_{\text {e,exp }}\right)$ and model-estimated $\left(\mathrm{q}_{e, e s t}\right)$ values, evaluated by means of the error measure (Equation 3)

$$
R M S=\sqrt{\sum\left[\left(q_{e, e s t}-q_{e, e x p}\right) / q_{e, e x p}\right]^{2}} / N
$$

where $\mathrm{q}_{e, \mathrm{exp}}$ and $\mathrm{q}_{e, e s t}$ are the experimental and calculated equilibrium adsorbed amounts, respectively, and $\mathrm{N}$ is the number of experimental isotherm points.

Adjustments to equilibrium models were made using Statistica Statsoft 8.0 software for nonlinear equations.

\section{Results and discussion}

\subsection{Preliminary results}

Preliminary chemical-activation tests were carried out in OPN residue-based carbons in the removal of MG in aqueous solution. The results shown in Table 1 demonstrate that the raw material treated with $\mathrm{H}_{3} \mathrm{PO}_{4}$ had statistically higher adsorbent yield compared with those activated with $\mathrm{NaOH}$ for the resulting material of 1-2 mm particle size. The carbons activated with $\mathrm{NaOH}$ had a lower density than those treated with $\mathrm{H}_{3} \mathrm{PO}_{4}$, indicating that this activation results in materials with a more brittle and fragile structure. The materials activated with $\mathrm{H}_{3} \mathrm{PO}_{4}$ had higher MG adsorption capacity $\left(\mathrm{q}_{\mathrm{f}}\right)$ than those impregnated with $\mathrm{NaOH}$, while carbons activated with $85 \% \mathrm{H}_{3} \mathrm{PO}_{4}$ showed a more efficient adsorptive behavior even than CAC.

In addition to the positive results of phosphoric acid in the tests, its use in the activation of lignocellulosic materials is well accepted in processes involving foods because of its non-polluting nature (Lim et al., 2010). Considering these results, the OPN-residue activated carbon impregnated with $85 \% \mathrm{H}_{3} \mathrm{PO}_{4}$ (OPNAC) was chosen for further study.

\subsection{Adsorbent characterization}

Figure 2 represents the microstructure of OPNAC at magnifications of $1000 \times(A)$ and $8000 \times(B)$. This figure shows that the sample has well-defined porous structures on its surface (Figure 2A) with tendency to formation of smaller pores within the larger pores (Figure $2 \mathrm{~B}$ ). Because of machine limitations, only macropores are visible in the images. Thus, BET analyzes were performed to better identify and classify the porous structure.

The OPNAC adsorption/desorption isotherms are shown in Figure 3. The isotherms obtained in the carbon activated with $\mathrm{H}_{3} \mathrm{PO}_{4}$ (impregnation rate of $100 \%$ ) were classified as Type IV because they showed hysteresis, indicating the start of the development of mesopores. Reffas et al. (2010) prepared carbons activated with coffee sediment treated with $\mathrm{H}_{3} \mathrm{PO}_{4}$ and observed Type-I isotherm in this material, typical of microporous materials for adsorbents prepared with a low impregnation rate (IR $<30 \%$ ). As impregnation was increased, there was an increase in hysteresis up to the point (IR > 120\%) where the response changed and the isotherm assumed Type-IV characteristics, associated with the presence of slit-shaped mesopores, similar to that shown in Figure 3. 
Table 1. Adsorbent yield, density and adsorption capacity $\left(\mathrm{q}_{\mathrm{t}}\right)$ of the activated carbons of OPN residue.

\begin{tabular}{cccc}
\hline Treatment & Adsorbent yield (\%) & Density $(\mathrm{g} \mathrm{L}-1)$ & $\mathrm{qt}(\mathrm{mg} / \mathrm{g})^{*}$ \\
\hline $20 \% \mathrm{NaOH}$ & $17.6185 \mathrm{a}$ & $0.1055 \mathrm{ab}$ & $0.8297 \mathrm{~b}$ \\
$15 \% \mathrm{NaOH}$ & $17.9823 \mathrm{a}$ & $0.1087 \mathrm{a}$ & $0.8426 \mathrm{c}$ \\
$10 \% \mathrm{NaOH}$ & $20.6676 \mathrm{a}$ & $0.1187 \mathrm{~b}$ & $0.8797 \mathrm{~d}$ \\
$72.2 \% \mathrm{H}_{3} \mathrm{PO}_{4}$ & $29.0767 \mathrm{~b}$ & $0.2033 \mathrm{c}$ & $0.9224 \mathrm{f}$ \\
$85.0 \% \mathrm{H}_{3} \mathrm{PO}_{4}$ & $30.8176 \mathrm{~b}$ & $0.2112 \mathrm{c}$ & $0.9531 \mathrm{~g}$ \\
$42.5 \% \mathrm{H}_{3} \mathrm{PO}_{4}$ & $31.8514 \mathrm{~b}$ & $0.2150 \mathrm{c}$ & $0.7753 \mathrm{a}$ \\
$\mathrm{CAC}$ & - & - & $0.9048 \mathrm{e}$ \\
\hline
\end{tabular}

* $10 \mathrm{mg} \mathrm{L}{ }^{-1} \mathrm{MG}$ in aqueous solution, $10 \mathrm{~g} \mathrm{~L}^{-1}$ of adsorbent, $6 \mathrm{~h}, 100 \mathrm{rpm}$. Data subjected to analysis of variance and Tukey's mean test at $5 \%$ significance level. Means in the column followed by the same letter are statistically equal to each other.

The surface parameters and pore structure derived from the nitrogen isotherms are compiled in Table 2. OPNAC presented both micro- and mesoporous structures $(41 \%$ and $15 \%$ of the total surface area, respectively). Specific surface area and total pore volume of OPNAC are comparable to those obtained in the carbons activated with $\mathrm{H} 3 \mathrm{PO} 4$ produced from coffee solid residues and corn cobs at high impregnation rates. OPNAC is more microporous than mesoporous even if the impregnation rate is high, but the macroporous area likely corresponds to the microporous area. This difference is attributed to the original porosity of raw materials used in the production of adsorbents (Zhang et al., 2012). The preparation of the adsorbent by activating defective coffee beans press cake (CADC) with $168 \%$ impregnation rate showed a much smaller surface area compared with OPNAC, confirming the significant effect that the precursor material has on the physical properties in the preparation of the adsorbent. Furthermore, the impregnation time used in this study, of $3 \mathrm{~min}$, is significantly shorter than the $3 \mathrm{~h}$ adopted by Reffas et al. (2010). However, the MG molecule is rather small $(1.58 \mathrm{~nm})$ and thus both mesopores ( 2 to $50 \mathrm{~nm}$ average diameter) and micropores (less than $2 \mathrm{~nm}$ average diameter) of the adsorbent must be accessible for the dye (International Union of Pure and Applied Chemistry, 1972).

The TG and DTG curves of OPNAC are shown in Figure 4. The thermal degradation of the material showed three major intervals for weight loss, a phenomenon clearly observed in the DTG curve. The first interval between $30^{\circ} \mathrm{C}$ and $200^{\circ} \mathrm{C}$ showed a mass loss of $16.78 \%$ corresponding to the loss of water molecules. Materials composed of lignin activated by acids show stability of the oxygenated groups up to an approximate temperature of $200{ }^{\circ} \mathrm{C}$, suggesting that the weight loss below this temperature is related to water evaporation (Ömeroğlu Ay et al., 2012; García-Rosales \& Colín-Cruz, 2010; Polovina et al., 1997). Ligno cellulosic materials have low stability at temperatures above $250{ }^{\circ} \mathrm{C}$, but the acid treatment increases this thermal stability (Álvarez et al., 2005). The main decomposition occurred in the temperature range of $200^{\circ} \mathrm{C}$ to $670^{\circ} \mathrm{C}$, associated with the weight loss of $69.83 \%$. The weight loss greater than $200^{\circ} \mathrm{C}$ is due to the degradation of oxygen groups of the activated-carbon surface. Carboxylic groups are less stable and decompose at $400{ }^{\circ} \mathrm{C}$, producing $\mathrm{CO}_{2}$. The third stage of decomposition of the sample occurs between the temperatures of $6700^{\circ} \mathrm{C}$ and $920^{\circ} \mathrm{C}$, with a weight loss of $7.16 \%$. Phenolic and carbonyl groups decompose at $800^{\circ} \mathrm{C}$ to produce $\mathrm{CO}$ and $\mathrm{CO}_{2}$ (Bandosz, 1999;

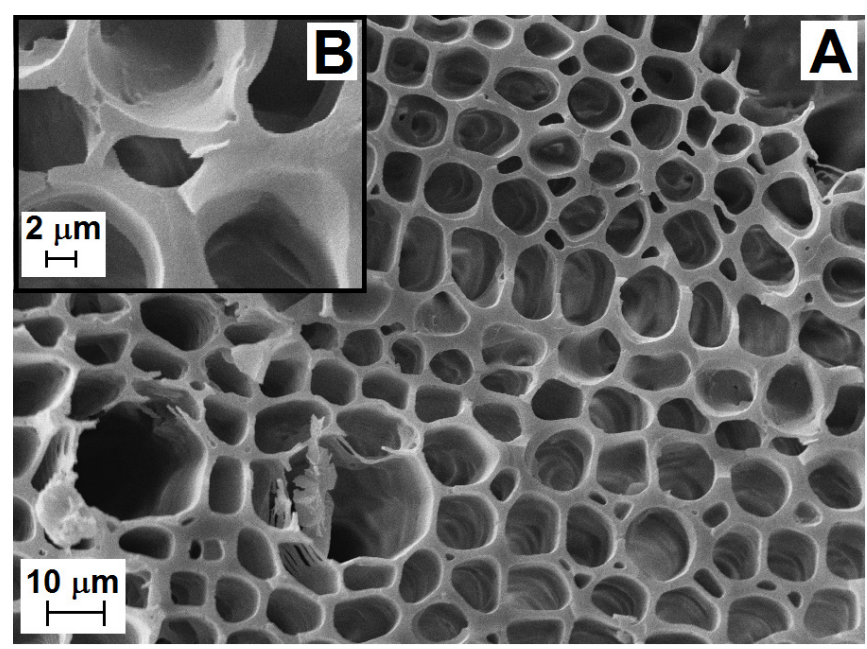

Figure 2. Scanning electron micrograph of OPNAC (A: 2000x, B: 8000x).

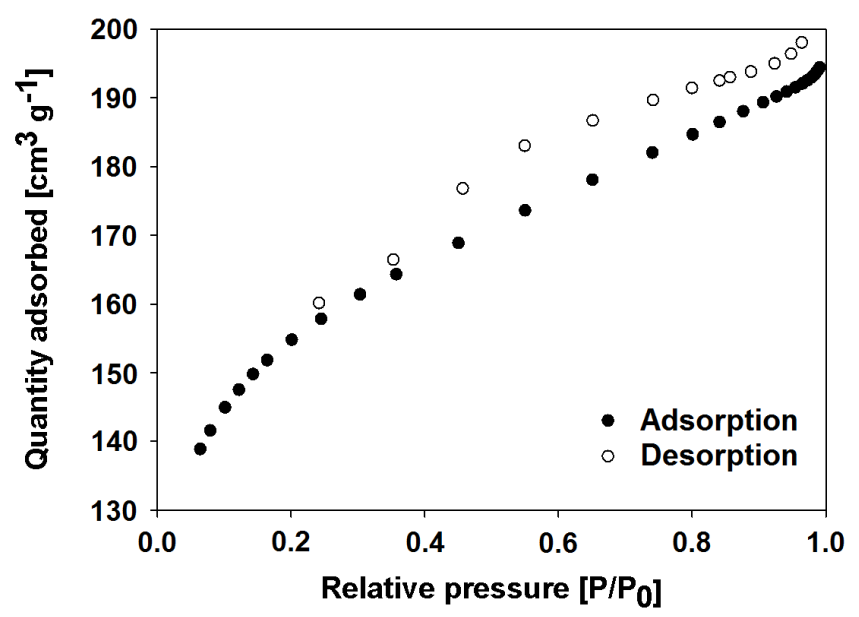

Figure 3. Adsorption/desorption. of $\mathrm{N}_{2}$ isotherm by OPNAC.

Hayashi et al., 2000; Polovina et al., 1997; Sun \& Webley, 2011; Tancredi et al., 2004). Thus, the highest percentage in mass was observed in the range referring to the oxygen and carboxyl groups, and the lowest in the phenolic and carbonyl groups. The total weight loss of the sample was $93.77 \%$ at around $920^{\circ} \mathrm{C}$, resulting in ash residues (Ömeroğlu Ay et al., 2012). 
Thermogravimetric studies show that during the carbonization of a lignocellulosic material, carboxyl groups are the most thermolabile oxygen groups, as they can be decomposed as $\mathrm{CO}_{2}$ at temperatures in the range of 100 to $400{ }^{\circ} \mathrm{C}$, while carboxylic anhydrides and lactones decompose in the range of $430660^{\circ} \mathrm{C}$. The other types of oxygen groups (phenols, ethers, carbonyls and quinones) are decomposed thermally as either $\mathrm{CO}$ or $\mathrm{CO}_{2}$ at temperatures above $600{ }^{\circ} \mathrm{C}$, the pyrone structures being the most thermally stable (decomposing at 900 to $1,200{ }^{\circ} \mathrm{C}$ ) (Bourke et al., 2007). Thus, to control the acidic or basic nature of the activated carbon produced, except for the intrinsic properties of the precursor material, the temperature and heating rates must be carefully controlled in the carbonization and activation process (Oliveira \& França, 2008).

The FTIR spectrum obtained for OPNAC is presented in Figure $5 \mathrm{~A}$ in comparison with the spectrum obtained for the OPN residue (B). The spectrum of the activated carbon (A) is similar to others shown in the literature for chemical activation of lignocellulosic materials by $\mathrm{H}_{3} \mathrm{PO}_{4}$ (Alves et al., 2013; Reffas et al., 2010). The bands between 1300 and $1000 \mathrm{~cm}^{-1}$, with maximum at 1240 (A) and 1026 (B) $\mathrm{cm}^{-1}$, are attributed to $\mathrm{P}=\mathrm{O}$ stretching vibrations (A) and $\mathrm{C}-\mathrm{O}$ stretching in acids, alcohols, phenols, ethers and esters (B). The significant difference between these bands confirms the effect of the activation procedure. The band at $1240 \mathrm{~cm}^{-1}(\mathrm{~A})$ is not present in the spectrum for OPN residue without chemical activation (B) and has been reported to become better defined with an increase in impregnation rate (Reffas et al., 2010). Bands at $1026 \mathrm{~cm}^{-1}$ (C-O) have been reported in association with the presence of lignin and hemicellulose esters (Suárez-García et al., 2002). Notice that these bands do not appear and/or are less evident in the activated carbon (A) in comparison with the OPN residue (B). The non-appearance of this band after treatment with phosphoric acid may be associated with the possibility of the $\mathrm{O}-\mathrm{H}$ grouping be participating in hydrogen bonding with the activating agent. When the $\mathrm{O}-\mathrm{H}$ group participates in hydrogen bonding, the $\mathrm{C}-\mathrm{O}$ bond becomes slightly weaker and, as a result, a reduction or absence of the absorption frequency is

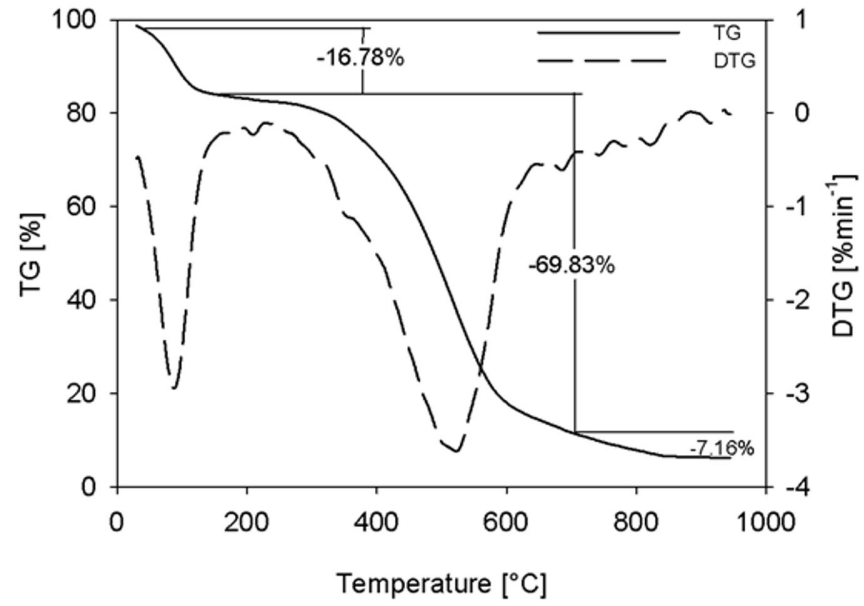

Figure 4. TG and DTG curves of OPNAC.

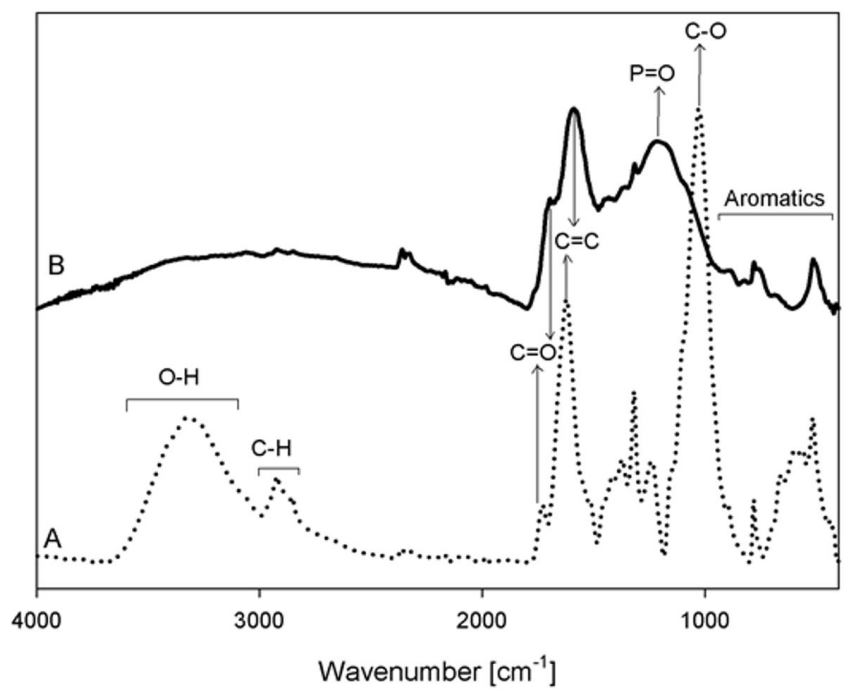

Figure 5. FTIR spectra of OPNAC (A) and OPN residue (B).

Table 2. Adsorbent pore characteristics.

\begin{tabular}{|c|c|c|c|c|c|}
\hline $\begin{array}{c}\text { Adsorbent } \\
\text { (impregnation rate) }\end{array}$ & $\begin{array}{l}\text { OPNAC } \\
(100 \%)\end{array}$ & $\begin{array}{l}\text { CCAC } \\
(168 \%)\end{array}$ & $\begin{array}{l}\text { DCAC } \\
(168 \%)\end{array}$ & $\begin{array}{c}\text { SGAC1 } \\
(30 \%)\end{array}$ & $\begin{array}{l}\text { SGAC2 } \\
(120 \%)\end{array}$ \\
\hline ST $\left(\mathrm{m}^{2} \mathrm{~g}^{-1}\right)$ & 712.081 & 893.7 & 490.8 & 514 & 745 \\
\hline $\mathrm{VT}\left(\mathrm{cm}^{3} \mathrm{~g}^{-1}\right)$ & 0.3105 & 0.612 & 0.277 & 0.280 & 0.446 \\
\hline Sme $\left(\mathrm{m}^{2} \mathrm{~g}^{-1}\right)$ & 107.125 & 192.4 & 31.0 & 103 & 417 \\
\hline$\%$ & 15 & 21 & 6 & 20 & 56 \\
\hline Vme $\left(\mathrm{cm}^{3} \mathrm{~g}^{-1}\right)$ & 0.128 & 0.248 & 0.034 & 0.066 & 0.279 \\
\hline$\%$ & 41 & 40 & 12 & 23 & 62 \\
\hline $\operatorname{Smi}\left(\mathrm{m}^{2} \mathrm{~g}^{-1}\right)$ & 296.04 & 610.6 & 421.5 & 311 & 158 \\
\hline$\%$ & 42 & 68 & 85 & 60 & 21 \\
\hline $\operatorname{Vmi}\left(\mathrm{cm}^{3} \mathrm{~g}^{-1}\right)$ & 0.137 & 0.288 & 0.199 & 0.169 & 0.100 \\
\hline$\%$ & 44 & 47 & 72 & 60 & 22 \\
\hline Ref. & $\begin{array}{c}\text { Present } \\
\text { study }\end{array}$ & $\begin{array}{l}\text { Alves } \\
\text { et al. (2013) }\end{array}$ & $\begin{array}{c}\text { Clark } \\
\text { et al. }(2012)\end{array}$ & $\begin{array}{c}\text { Reffas } \\
\text { et al. (2010) }\end{array}$ & $\begin{array}{l}\text { Reffas } \\
\text { et al. (2010) }\end{array}$ \\
\hline
\end{tabular}

$\mathrm{V}_{\mathrm{T}}$ : total pore volume; $\mathrm{S}_{\mathrm{T}}$ : total surface area; $\mathrm{S}_{\mathrm{me}}$ : mesopore surface area; $\mathrm{V}_{\mathrm{me}}$ : mesopore volume; $\mathrm{S}_{\mathrm{mi}}$ micropore surface area; $\mathrm{V}_{\text {mi: }}$ micropore volume; $\mathrm{CCAC}$ : corn cobs activated carbon; DCAC: defective coffee beans press cake activated carbon; SGAC1: spent coffee grounds activated carbon with low impregnation rate; SGAC2: spent coffee grounds activated carbon with high impregnation rate. All adsorbents were impregnated with $\mathrm{H}_{3} \mathrm{PO}_{4}$. 
observed (Barbosa, 2008). The effects of heat treatment by FTIR analysis on carbon activated with phosphoric acid was investigated (Guo \& Rockstraw, 2007) and concluded that at carbonization temperatures above $300^{\circ} \mathrm{C}$, the incorporation of phosphate grouping was favored because a band around $1250 \mathrm{~cm}^{-1}$ appeared after this temperature. The broad band at $3600-3000 \mathrm{~cm}^{-1}$ is attributed to hydrogen bonds in carboxyl or phenolic groups. A reduction in the intensity of these bands after activation could be associated with interactions between the $\mathrm{O}-\mathrm{H}$ group and the activating agent (Alves et al., 2013). The band between $3100-2800 \mathrm{~cm}^{-1}$ is related to the C-H bond (Milicevic et al., 2012).

\subsection{Effect of contact time on adsorption}

The effects of contact time on adsorption in single component solution and tertiary aqueous solution by OPNAC and CAC were investigated and results are displayed in Figure 6.
The absorption of MG in the single component solution (Figure 6) increased with the contact time for up to $3 \mathrm{~h}$ for OPNAC and $6 \mathrm{~h}$ for CAC, with equilibrium achieved after this point. The adsorption equilibrium was similar for both adsorbents, with $4.5 \mathrm{mg} \mathrm{g}^{-1} \mathrm{MG}$. The adsorption occurred rapidly in the initial stage (before $45 \mathrm{~min}$ ) due to the greater availability of active binding sites (Leng et al., 2015). In the last stage, the adsorption became a controlled binding process due to the lower availability of active sites (Saha et al., 2010). In the tertiary aqueous solution (Figure 6B), OPNAC had a faster adsorption of MG than CAC did for up to $12 \mathrm{~h}$ of contact, and after $24 \mathrm{~h}$ the adsorption was $4.3 \mathrm{mg} \mathrm{g}^{-1}$, showing slightly lower MG adsorption than in the single systems.

In the case of BSA and GLU, minimum adsorption is desired for the process under study. For this evaluation, adsorption tests were carried out in single systems. OPNAC had the higher adsorption of BSA, reaching $35.9 \mathrm{mg} \mathrm{g}^{-1}$, while CAC adsorbed

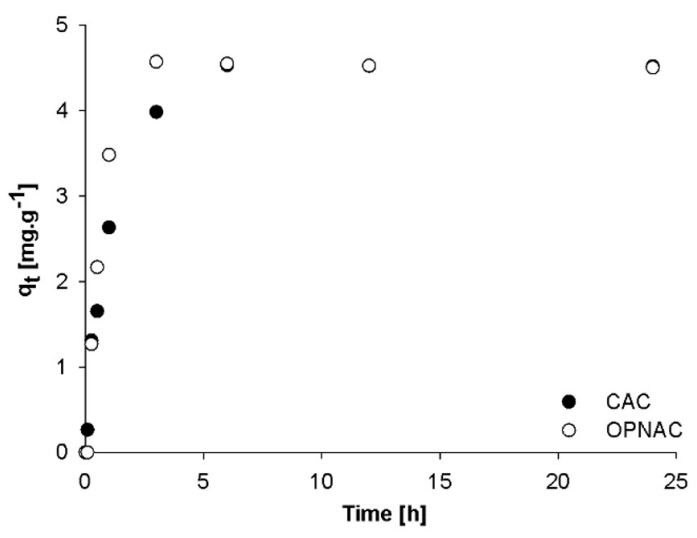

(A)

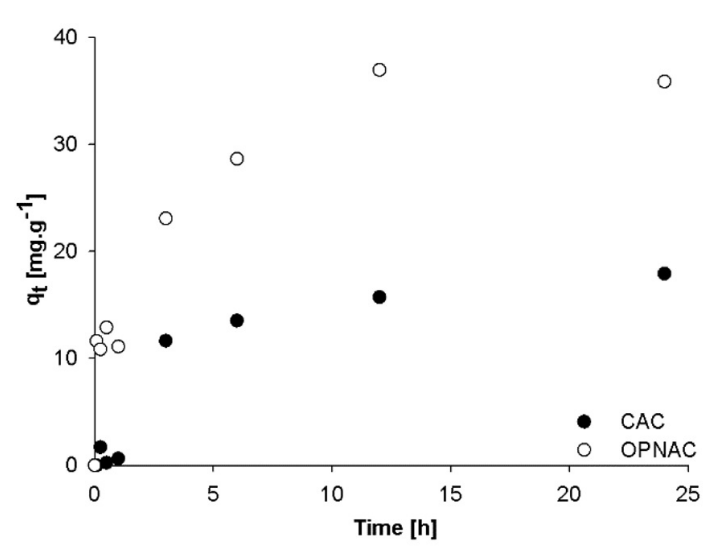

(C)

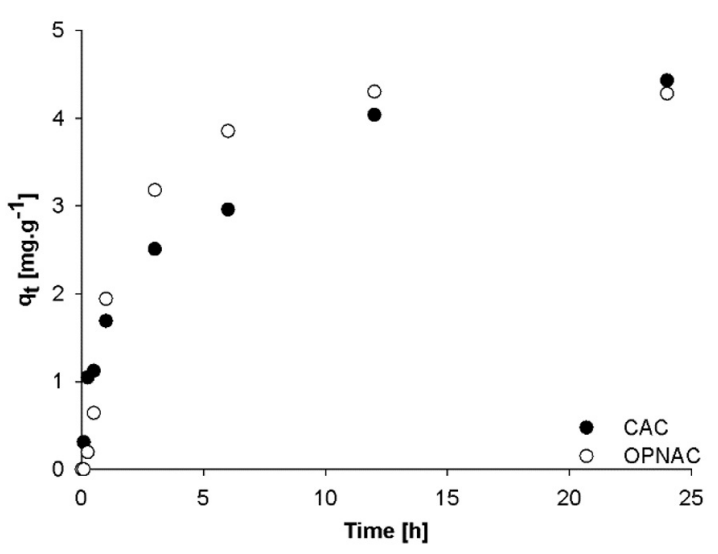

(B)

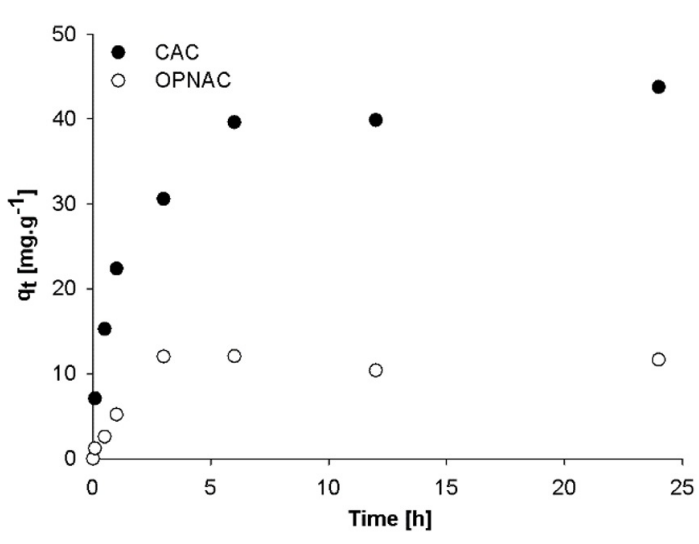

(D)

Figure 6. Effect of contact time by CAC and OPNAC $\left(25^{\circ} \mathrm{C}\right.$, adsorbent dose: $\left.10 \mathrm{~g} \mathrm{~L}^{-1}\right)$ on: (A) MG adsorption in single component solution with initial concentration of $50 \mathrm{mg} \mathrm{L}^{-1} \mathrm{MG}$; (B) MG adsorption in ternary aqueous solution with initial concentrations of $50 \mathrm{mg} \mathrm{L}^{-1} \mathrm{MG} 500 \mathrm{mg} \mathrm{L}^{-1} \mathrm{BSA}$ and $1500 \mathrm{mg} \mathrm{L}^{-1} \mathrm{GLU}$; (C) BSA adsorption in single component solution with initial concentration of $500 \mathrm{mg} \mathrm{L}^{-1} \mathrm{BSA}$; (D) GLU adsorption in single component solution with initial concentration of $1500 \mathrm{mg} \mathrm{L}^{-1} \mathrm{BSA}$. 
$17.9 \mathrm{mg} \mathrm{g}^{-1}$ after $24 \mathrm{~h}$ of contact (Figure 6C). A different response occurred in adsorption of GLU (Figure 6D), with adsorbent CAC having the greatest effect on the adsorption of GLU (43.7 $\mathrm{mg} \mathrm{g}^{-1}$ ), whereas OPNAC adsorbed only $11.6 \mathrm{mg} \mathrm{g}^{-1}$ after $24 \mathrm{~h}$. However, as observed in Fig $06 \mathrm{~A}$ and $\mathrm{B}$, the results for the MG-adsorption capacity by OPNAC did not show significant differences between the single and tertiary system, demonstrating the existence of a strong affinity of this adsorbent for the dye.

\subsection{Adsorption equilibrium}

The adsorption isotherms of OPNAC at $25^{\circ} \mathrm{C}$ are shown in Figure 7. Observing the isotherms, it can be seen that the curve for CAC indicates a favorable process, and for OPNAC a highly favorable process in MG removal. OPNAC has a greater

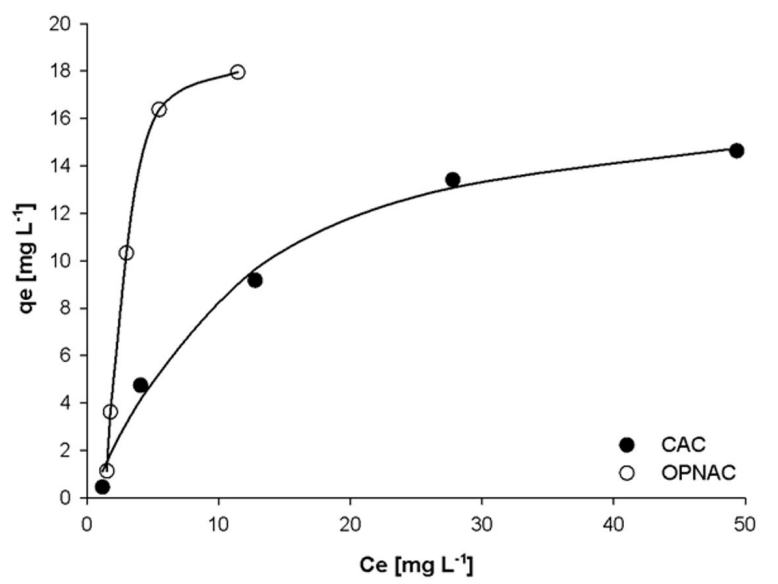

Figure 7. Adsorption isotherms for the adsorption of MG by OPNAC and CAC: Langmuir-Freundlich fit. adsorption capacity than the CAC sample does. The activation of rice husks with $\mathrm{H}_{3} \mathrm{PO}_{4}$ also obtained good MG-adsorption results (Rahman et al., 2005).

The models used to assess the balance of OPNAC and CAC in MG adsorption were the Langmuir, Freundlich, Redlich-Peterson and Langmuir-Freundlich (Table 3). The study of single component solutions is important for establishing the adsorption mechanisms that occur in the evaluated system, allowing the definition of the adsorption conditions that facilitate the removal of component from the system (Clark et al., 2012).

The data displayed in Table 3 show that the adsorption of MG was best described by the Langmuir-Freundlich model. This model can describe both the Langmuir and Freundlich adsorption behaviors, which are usually better adjusted in adsorbents of heterogeneous surface (Janoš et al., 2009).

For OPNAC, it was observed that the occurrence of micropores prevailed over mesopores, but the surface area of the macropores is probably equivalent to that of micropores (item 3.2). These characteristics of porous structure contribute to the diffusion of solutes by the processes of physical adsorption in mesopores and macropores and chemical adsorption in active sites located within the micropores. The chemical and physical adsorption rates, in the process employing OPNAC as adsorbent, are probably equivalent.

By the Langmuir model, OPNAC had a higher maximum adsorption capacity $\mathrm{q}_{0}(36.008 \mathrm{mg} / \mathrm{g})$ than CAC $\operatorname{did}(19.108 \mathrm{mg} / \mathrm{g})$, showing that OPNAC has a high adsorption capacity for MG. The $\mathrm{K}_{\mathrm{F}}(2.379)$ of OPNAC calculated from the Freundlich model is greater than the $\mathrm{K}_{\mathrm{F}}(2.055)$ of CAC, confirming that OPNAC has greater affinity for MG.

Table 3. Adsorption isotherm models and fitting parameters.

\begin{tabular}{|c|c|c|c|}
\hline Model & Adsorbent & $\mathrm{R}^{2}$ & RMS \\
\hline Langmuir & $\begin{array}{c}\text { CAC } \\
K_{L}=0.074 \quad q_{o}=19.108\end{array}$ & 0.987 & 0.172 \\
\hline$q_{e}=\frac{q_{o} K_{L} C_{e}}{1+K_{L} C_{e}}$ & $\begin{array}{c}\text { OPNAC } \\
K_{L}=0.105 \quad q_{o}=36,008\end{array}$ & 0.858 & 0.303 \\
\hline Freundlich & $\begin{array}{c}\text { CAC } \\
K_{F}=2.379 \quad n=2.055\end{array}$ & 0.936 & 0.228 \\
\hline$q_{e}=K_{F} C_{e}^{1 / n}$ & $\begin{array}{c}\text { OPNAC } \\
K_{F}=3.846 \quad n=1.472\end{array}$ & 0.812 & 0.342 \\
\hline $\begin{array}{l}\text { Redlich-Peterson } \\
q_{e}=\frac{a_{R P} C_{e}}{1+K_{R P} C_{e}^{n}}\end{array}$ & $\begin{array}{c}\text { CAC } \\
\text { OPNAC }\end{array}$ & $\begin{array}{l}0.991 \\
0.910\end{array}$ & $\begin{array}{l}0.172 \\
0.238\end{array}$ \\
\hline $\begin{array}{l}\text { Langmuir-Freundlich } \\
\qquad q_{e}=\frac{q_{o}\left(K_{L} C_{e}\right)^{n}}{1+\left(K_{L} C_{e}\right)^{n}}\end{array}$ & $\begin{array}{c}\text { CAC } \\
\text { OPNAC }\end{array}$ & $\begin{array}{l}0.991 \\
0.997\end{array}$ & $\begin{array}{l}0.164 \\
0.206\end{array}$ \\
\hline
\end{tabular}

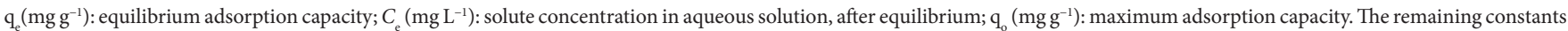
are empirical parameters associated with each specific model. 


\section{Conclusions}

This study demonstrates the feasibility of using OPN residue in the development of low-cost adsorbent for the removal of MG, as well as promoting sustainability when applied in the process of pigment-removal of OPNH. The chemical activation with $85 \% \mathrm{H}_{3} \mathrm{PO}_{4}$ (OPNAC) favored the formation of micro-mesoporous structure with predominance of acid functional groups and the increase of selective adsorption capacity of MG compared to CAC. Adsorption isotherms were favorable to the studied process and the Langmuir-Freundlich model which best described the process in equilibrium.

\section{Acknowledgements}

The authors acknowledge the financial support from Brazilian Government Agencies (CAPES, CNPq and FAPEMIG) and the technical analysis support (UFMG Chemistry Department, Embrapa Instrumentation and UFLA Plant Pathology Department).

\section{Nomenclature}

AC - activated carbon

BET - BrunauereEmmette Teller method

BSA - bovine serum albumin

$\mathrm{C}_{0}$ - adsorbate concentration at initial time $\left(\mathrm{mg} \mathrm{L}^{-1}\right)$

$C_{\mathrm{e}}$ - adsorbate concentration at equilibrium $\left(\mathrm{mg} \mathrm{L}^{-1}\right)$

$\mathrm{C}_{\mathrm{t}-}$ adsorbate concentration at sampling times $\left(\mathrm{mg} \mathrm{L}^{-1}\right)$

CAC - commercial activated carbon

CCAC - corn cobs activated carbon

DCAC - defective coffee beans press cake activated carbon

DTG - derivative thermogravimetry

FTIR - Fourier transform infrared

GLU - anidrous glucose PA

IR - impregnationratio (\%)

MG - malachite green

$\mathrm{N}$ - number of experimental isotherm points.

OPN - ora-pro-nobis (Pereskiaaculeata Miller)

OPNAC - activated carbono based on Pereskiaaculeata Millerresidues

OPNH - hydrocolloids of Pereskiaaculeata Miller

$\mathrm{q}_{\mathrm{o}}$ - maximum adsorption capacity $\left(\mathrm{mg} \mathrm{g}^{-1}\right)$

$\mathrm{q}_{\mathrm{e}_{-}}$equilibrium adsorption capacity $\left(\mathrm{mg} \mathrm{g}^{-1}\right)$

$\mathrm{q}_{\mathrm{e}, \text { est }}$ - calculated equilibrium adsorption capacity $\left(\mathrm{mg} \mathrm{g}^{-1}\right)$

$\mathrm{q}_{\mathrm{e}, \exp }$ - experimental equilibrium adsorption capacity $\left(\mathrm{mg} \mathrm{g}^{-1}\right)$

RMS - root mean square

SEM - scanning electron microscopy
SGAC1 - spent coffee grounds activated carbon with low impregnation rate

SGAC2 - spent coffee grounds activated carbon with high impregnation rate

$\mathrm{S}_{\mathrm{me}}$ - mesopore surface area $\left(\mathrm{m}^{2} \mathrm{~g}^{-1}\right)$

$\mathrm{S}_{\mathrm{mi}}-$ micropore surface area $\left(\mathrm{m}^{2} \mathrm{~g}^{-1}\right)$

$\mathrm{S}_{\mathrm{T}}-$ total surface area $\left(\mathrm{m}^{2} \mathrm{~g}^{-1}\right)$

TG - thermogravimetry

$\mathrm{V}$ - volume of the solution (L)

$\mathrm{V}_{\mathrm{me}}$ - mesopore volume $\left(\mathrm{cm}^{3} \cdot \mathrm{g}^{-1}\right)$

$\mathrm{V}_{\mathrm{mi}}$ - micropore volume $\left(\mathrm{cm}^{3} \cdot \mathrm{g}^{-1}\right)$

$\mathrm{V}_{\mathrm{T}}$ - total pore volume $\left(\mathrm{cm}^{3} \cdot \mathrm{g}^{-1}\right)$

$\mathrm{W}_{1 \text { - }}$ weight of dried OPN activated carbon (g)

$\mathrm{W}_{0}$ - weight of OPN residue $(\mathrm{g})$

\section{References}

Álvarez, P., Santamaría, R., Blanco, C., \& Granda, M. (2005). Thermal degradation of lignocellulosic materials treated with several acids. Journal of Analytical and Applied Pyrolysis, 74(1-2), 337-343. http:// dx.doi.org/10.1016/j.jaap.2004.11.030.

Alves, C. C. O., Franca, A. S., \& Oliveira, L. S. (2013). Removal of Phenylalanine from aqueous solutions with thermo-chemically modified corn cobs as adsorbents. Lebensmittel-Wissenschaft + Technologie, 51(1), 1-8. http://dx.doi.org/10.1016/j.lwt.2012.11.012.

Bandosz, T. J. (1999). Effect of pore structure and surface chemistry of virgin activated carbons on removal of hydrogen sulfide. Carbon, 37(3), 483-491. http://dx.doi.org/10.1016/S0008-6223(98)00217-6.

Barbosa, L. C. A. (2008). Espectroscopia no infravermelho na caracterização de compostos orgânicos. Viçosa: UFV.

Bourke, J., Manley-Harris, M., Fushimi, C., Dowaki, K., Nunoura, T., \& Antal, M. J. (2007). Do all carbonized charcoals have the same chemical structure? 2. A model of the chemical structure of carbonized charcoal. Industrial \& Engineering Chemistry Research, 46(18), 5954-5967. http://dx.doi.org/10.1021/ie070415u.

Bradford, M. M. (1976). A Rapid and sensitive method for the quantitation of microgram quantities of protein utilizing the principle of proteindye binding. Analytical Biochemistry, 72(1-2), 248-254. PMid:942051. http://dx.doi.org/10.1016/0003-2697(76)90527-3.

Capitani, M. I., Ixtaina, V. Y., Nolasco, S. M., \& Tomás, M. C. (2013). Microstructure, chemical composition and mucilage exudation of Chia (Salvia Hispanica L.) nutlets from Argentina. Journal of the Science of Food and Agriculture, 93(15), 3856-3862. PMid:23900918. http://dx.doi.org/10.1002/jsfa.6327.

Clark, H. C., Alves, C. C. C., Franca, A. S., \& Oliveira, L. S. (2012). Evaluation of the performance of an agricultural residue-based activated carbon aiming at removal of phenylalanine from aqueous solutions. Lebensmittel-Wissenschaft + Technologie, 49(1), 115-161. http://dx.doi.org/10.1016/j.lwt.2012.04.026.

Conceição, M. C., Junqueira, L. A., Guedes Silva, K. C., Prado, M. E. T., \& de Resende, J. V. (2014). Thermal and microstructural stability of a powdered gum derived from Pereskia Aculeata miller leaves. Food Hydrocolloids, 40, 104-114. http://dx.doi.org/10.1016/j. foodhyd.2014.02.015. 
Dickinson, E. (2003). Hydrocolloids at interfaces and the influence on the properties of dispersed systems. Food Hydrocolloids, 17(1), 25-39. http://dx.doi.org/10.1016/S0268-005X(01)00120-5.

Dische, Z. (1962). General color reactions. In R. L. Whistler \& M. L. Wolfran (Eds.), Carbohydrates chemistry (Vol. 1, pp. 477-512). New York: Academic Press.

García-Rosales, G., \& Colín-Cruz, A. (2010). Biosorption of lead by Maize (Zea Mays) stalk sponge. Journal of Environmental Management, 91(11), 2079-2086. PMid:20615602. http://dx.doi.org/10.1016/j. jenvman.2010.06.004.

Guo, Y., \& Rockstraw, D. A. (2007). Physicochemical properties of carbons prepared from Pecan Shell by phosphoric acid activation. Bioresource Technology, 98(8), 1513-1521. PMid:16973352. http:// dx.doi.org/10.1016/j.biortech.2006.06.027.

Hayashi, J., Kazehaya, A., Muroyama, K., \& Watkinson, A. P. (2000). Preparation of activated carbon from lignin by chemical activation. Carbon, 38(13), 1873-1878. http://dx.doi.org/10.1016/S00086223(00)00027-0.

International Union of Pure and Applied Chemistry - IUPAC (1972). Manual of symbols and terminology: appendix 2. Part I: colloid and surface chemistry. Pure and Applied Chemistry, 31, 578.

Janoš, P., Coskun, S., Pilařová, V., \& Rejnek, J. (2009). Removal of basic (Methylene Blue) and acid (Egacid Orange) dyes from waters by sorption on chemically treated wood shavings. Bioresource Technology, 100(3), 1450-1453. PMid:18848777. http://dx.doi.org/10.1016/j. biortech.2008.06.069.

Leng, L., Yuan, X., Zeng, G., Shao, J., Chen, X., Wu, Z., Wang, H., \& Peng, X. (2015). Surface characterization of rice husk bio-char produced by liquefaction and application for cationic dye (Malachite Green) adsorption. Fuel, 155, 77-85. http://dx.doi.org/10.1016/j. fuel.2015.04.019.

Lim, W. C., Srinivasakannan, C., \& Balasubramanian, N. (2010). Activation of palm shells by phosphoric acid impregnation for high yielding activated carbon. Journal of Analytical and Applied Pyrolysis, 88(2), 181-186. http://dx.doi.org/10.1016/j.jaap.2010.04.004.

Lima, F. A. Jr, Conceição, M. C., Resende, J. V., Junqueira, L. A., Pereira, C. G., \& Prado, M. E. T. (2013). Response surface methodology for optimization of the mucilage extraction process from pereskia aculeata miller. Food Hydrocolloids, 33(1), 38-47. http://dx.doi. org/10.1016/j.foodhyd.2013.02.012.

Mall, I. D., Srivastava, V. C., Agarwal, N. K., \& Mishra, I. M. (2005). Adsorptive removal of malachite green dye from aqueous solution by bagasse fly ash and activated carbon-kinetic study and equilibrium isotherm analyses. Colloids and Surfaces. A, Physicochemical and Engineering Aspects, 264(1-3), 17-28. http://dx.doi.org/10.1016/j. colsurfa.2005.03.027.

Merce, A. L. R., Landaluze, J. S., Mangrich, A. S., Szpoganicz, B., \& Sierakowski, M. R. (2001). Complexes of arabinogalactan of Pereskia Aculeata and $\mathrm{Co} 2+, \mathrm{Cu} 2+, \mathrm{Mn} 2+$, and $\mathrm{Ni} 2+$. Bioresource Technology, 76(1), 29-37. PMid:11315807. http://dx.doi.org/10.1016/ S0960-8524(00)00078-X.

Milicevic, S., Boljanac, T., Martinovic, S., Vlahovic, M., Milosevic, V., \& Babic, B. (2012). Removal of copper from aqueous solutions by low cost adsorbent-kolubara lignite. Fuel Processing Technology, 95, 1-7. http://dx.doi.org/10.1016/j.fuproc.2011.11.005.

Oliveira, L. S., \& França, A. S. (2008). Low-cost adsorbent from agrifood wastes. In V. Lorenzo \& M. N. B. Greco (Eds.), Food science and technology: new research (39 p.). New York: Nova Publisher.

Ömeroğlu Ay, Ç., Özcan, A. S., Erdoğan, Y., \& Özcan, A. (2012). Characterization of Punica Granatum L. Peels and quantitatively determination of its biosorption behavior towards lead(II) Ions and Acid Blue 40. Colloids and Surfaces. B, Biointerfaces, 100, 197-204. PMid:22766298. http://dx.doi.org/10.1016/j.colsurfb.2012.05.013.

Petera, B., Delattre, C., Pierre, G., Wadouachi, A., Elboutachfaiti, R., Engel, E., Poughon, L., Michaud, P., \& Fenoradosoa, T. A. (2015). Characterization of arabinogalactan-rich mucilage from cereus triangularis cladodes. Carbohydrate Polymers, 127, 372-380. PMid:25965496. http://dx.doi.org/10.1016/j.carbpol.2015.04.001.

Polovina, M., Babić, B., Kaluderović, B., \& Dekanski, A. (1997). Surface characterization of oxidized activated carbon cloth. Carbon, 35(8), 1047-1052. http://dx.doi.org/10.1016/S0008-6223(97)00057-2.

Rahman, I. A., Saad, B., Shaidan, S., \& Sya Rizal, E. S. (2005). Adsorption characteristics of malachite green on activated carbon derived from rice husks produced by chemical-thermal process. Bioresource Technology, 96(14), 1578-1583. PMid:15978990. http://dx.doi. org/10.1016/j.biortech.2004.12.015.

Reffas, A., Bernardet, V., David, B., Reinert, L., Lehocine, M. B., Dubois, M., Batisse, N., \& Duclaux, L. (2010). Carbons prepared from coffee grounds by $\mathrm{H} 3 \mathrm{PO} 4$ activation: characterization and adsorption of methylene blue and nylosan red N-2RBL. Journal of Hazardous Materials, 175(1-3), 779-788. PMid:19942347. http:// dx.doi.org/10.1016/j.jhazmat.2009.10.076.

Sáenz, C., Sepúlveda, E., \& Matsuhiro, B. (2004). Opuntia Spp Mucilage’s: a functional component with industrial perspectives. Journal of Arid Environments, 57(3), 275-290. http://dx.doi.org/10.1016/ S0140-1963(03)00106-X.

Saha, P., Chowdhury, S., Gupta, S., \& Kumar, I. (2010). Insight into adsorption equilibrium, kinetics and thermodynamics of Malachite Green onto Clayey Soil of Indian origin. Chemical Engineering Journal, 165(3), 874-882. http://dx.doi.org/10.1016/j.cej.2010.10.048.

Salehi, F., Kashaninejad, M., Tadayyon, A., \& Arabameri, F. (2014). Modeling of extraction process of crude Polysaccharides from Basil seeds (Ocimum Basilicum L.) as affected by process variables. Journal of Food Science and Technology, 52(8), 5220-5227. PMid:26243945.

Suárez-García, F., Martínez-Alonso, A., \& Tascón, J. M. D. (2002). A Comparative study of the thermal decomposition of apple pulp in the absence and presence of phosphoric acid. Polymer Degradation \& Stability, 75(2), 375-383. http://dx.doi.org/10.1016/S01413910(01)00243-9.

Sun, Y., \& Webley, P. A. (2011). Preparation of actived carbons from corncob with large specific surface area by a variety of chemical activators and their aplication in gas storage. Chemical Engineering Journal, 162(3), 883-892. http://dx.doi.org/10.1016/j.cej.2010.06.031.

Takeiti, C. Y., Antonio, G. C., Motta, E. M., Collares-Queiroz, F. P., \& Park, K. J. (2009). Nutritive Evaluation of a non-conventional leafy vegetable (Pereskia Aculeata Miller). International Journal of Food Sciences and Nutrition, 60(Suppl 1, Suppl 1), 148-160. PMid:19468927. http://dx.doi.org/10.1080/09637480802534509.

Tancredi, N., Medero, N., Möller, F., Píriz, J., Plada, C., \& Cordero, T. (2004). Phenol adsorption onto powdered and granular activated carbon, prepared from eucalyptus wood. Journal of Colloid and Interface Science, 279(2), 357-363. PMid:15464799. http://dx.doi. org/10.1016/j.jcis.2004.06.067.

Vardhanabhuti, B., \& Ikeda, S. (2006). Isolation and characterization of hydrocolloids from monoi (Cissampelos Pareira) leaves. Food Hydrocolloids, 20(6), 885-891. http://dx.doi.org/10.1016/j. foodhyd.2005.09.002.

Zhang, Y., Ghaly, A. E., \& Li, B. (2012). Physical properties of corn residues. American Journal of Biochemistry and Biotechnology, 8(2), 44-53. http://dx.doi.org/10.3844/ajbbsp.2012.44.53. 